\title{
Through Networks and Ordeal Narratives, or Making Meaning of One's Displacement: Recent Labour Migration from Western Ukraine
}

NATALIA SHOSTAK

\begin{abstract}
I was born in the village of Hurtkiv in the Sokal District.[I] All my childhood was spent there. [pause] Then I got married and lived there for a year with the parents. My husband worked in the mine. I worked in OshchadBank [Savings Bank, N.S.] after graduating from the institute, and worked there for 20 years. All my life actually I worked in Sokal, in the bank. [pause, Anna thinks a bit] .. Together with my husband we raised a house during that period, while we worked there. He was earning good money in the mine at that time. I earned very well in the bank as well. [pause] We lived very well.
\end{abstract}

Anna begins her life story in the kitchen of a student dormitory at one of the Lviv universities. In her fifties, she holds the respected position of superintendent at a prestigious university, is a proud mother of two, loving wife to her husband, and caring daughter to her ill mother, who lives in the countryside. We have met and talked numerous times, but today both of us are trying to grasp themeaning, scope and the impact of the mass labour migration which started in Ukraine in the mid-1990s.

Since the collapse of the Soviet Union in 1991, the economic transition has not been easy on ordinary Ukrainians. Marked by high inflation, it left many with no jobs or with devalued salaries. Anna went abroad twice to earn money for her family when there was none to be earned in her region. Today,[2] with me as an audience, she attempts to justify to herself the decisions and moves that led her aw ay from home and family. I am trying to develop a larger perspective on her and others' migrational routes and their meanings. Throughout my career as anthropologist, I have intimately discussed the subject of going abroad without a return ticket 
with many immigrant women. Recently I started systematically recording the life stories of migrant women from Ukraine who went to work abroad, either in Europe or in Canada.[3] Anna's is one of the 14 interviews I have conducted thus far for this ongoing project "Making Meaning of One's Life: An Oral History of Migrant Women from Western Ukraine (at the turn of the 21st century)."

The issue I would like to address here is how through voicing (externalizing) one's story of venturing abroad, one embarks upon a path towards better justifying and becoming reconciled with the difficult decisions and moves one has had to make in life. Such a path - towards a better understanding of oneself - is cleared through thick groves of human networks and the networks of meaning one has to navigate. Thus, I argue that the meanings of a person's journey, both in terms of geography and personal growth, are not only externalized through, but comprehended in narrative and re-evaluated in subsequent conversations against these networks of relationships and networks of meaning.

Displacement narratives, with their display of an informant's embedded-ness in various sending and receiving networks, allow the researcher to access and evaluate often not easily accessible bundles of semi-legal relationships and social circles in the home and host communities. These narratives also allow us to see how, on the one hand, the migrant's embedded-ness in these sending and receiving networks in home and host communities inform her decisions to move from one life situation and geographical location to another and, on the other, how participation in these networks informs her subsequent narrative rationalization and justification of these moves and life choices. Of course, to more fully address this question one would have to converse with a representative number of individuals at several crucial points in their lives: prior to migrating, during their work abroad, and upon their return. In my project I am dealing with the recollections of such participation from one vantage point: after their return.

The repercussions of these questions extends beyond the individual informants, since it is at the intersection of personal meaning-making and the workings of macro-history that new cultural myths and narratives are being created for the new communities born out of this shared historical experience. In the case of the new Ukrainian presence in the "West," for example, which is about to give birth to a new (post-Soviet) Ukrainian diaspora, stories like Anna's and many others will constitute the 
collective memory of "how it all began" and will thus contribute to this future diaspora's origin story.

Too often, ethnography and macro-cultural analysis are a less than perfect fit. There is, as Sally Moore has put it (1987: 731), a "zone of ignorance" between the macro and micro levels of analysis. And as Hannerz suggests, there is a need to expand ethnography into the space of macro-analysis in order to reach a more grounded imagery of larger social processes (Hannerz 1992: 21-22). To understand how individual migrants justify their own search for a better future, how they reclaim their human dignity, and how they add meaning to their experiences of displacement is to understand the human agency behind the grand post-socialist transformations and population moves within Europe.

As (an independent) Ukraine emerged, people ended up with next to nothing.

For everyone, there was no work to do at work! We go to work, and no one pays us. Our oldest daughter entered her first year at the Theological Academy, she spent one year there, and after that we had no money to pay for her education. Then my husband went to Moscow to work. [...] He left the mine because they had not paid him his salary for two years. For two years they hadn't paid them any money! I was paid, but very little and with great delays. [...] He worked in Moscow for two seasons, and when he went there for the third time, after he finished working they did not pay him. They only gave him enough to travel back home, and they even threatened them. So all in all, they paid him only for two months but did not pay him for the other half a year he worked for them. [pause] He came back very disheartened, very depressed and disillusioned in life. By that time, our younger daughter had also become a student, and it really seemed like we were in a deadend situation. We just did not know how to get out of it. [...]

Then he finally went there [Spain, N.S], in 1997 [...] From the very beginning it was so difficult for him. So difficult! One cannot describe this in words. It took him three and a half hours to get to work and just as long to return. He lived in Madrid. [pause] And he is still there [as of July 2003, N.S.]

This new Ukrainian diasporic community - of labour migrants and their networks in Europe - has been forming for almost a decade due to the continuing economic difficulties that common people have been facing in today's Ukraine, especially in rural communities. The loss of population, disintegration of families, emergence of a new generation of children growing up without parents, who work abroad for years, and other 
factors all contribute to the overall negative image labour migration has acquired in Ukraine in the media, among policy makers, sociologists, historians and the like. Serious scholarly attention of this social phenomenon is long overdue. Only recently have some thorough sociological studies at the level of macro-analysis been published in Ukraine and abroad (Prybytkova 2002, 2003; Freijka 1999).

It has been estimated that between six and seven million Ukrainians are currently working abroad. Sociologists claim that one-quarter of them will never return (Vynnychenko 2002). According to the Ukrainian Foreign Ministry, in 2002 there were 1.3 million Ukrainians working in Russia, 300,000 in Poland, between 200,000 and 500,000 in Italy, 200,000 in Czech Republic, 150,000 in Portugal (where they are the third largest minority), 100,000 in Spain and other countries (Maksymiuk 2003). This data concerns only the legal migrants, with official contracts. Sociologists say that the total number, including illegal workers, may be two or three times higher (Susak 2003).

From the perspective of macro-history, one should also see a positive moment in this social process for the migrants' homeland. In two, three or five decades, depending on how soon and how well these populations establish themselves in their respective host societies, they will already be a diaspora, rather than just long-term migrants; they will grow into a community, rather than existing in scattered bundles of networks of individuals, each pursuing her own private goals while abroad. In comparison, the first immigration wave to Canada, which last for 23 years at the turn of the 20th century, yielded 170,000 individuals from Western Ukraine. With subsequent immigration waves throughout the rest of the 20th century, today in Canada there are about one million Ukrainian Canadians, who constitute one of the most viable and vital ethnic groups in Canadian society. Today's migrational flows are more intense, faster, and more voluminous, and one would expect a significant increase in the Ukrainian population in the European Union much earlier than in a hundred years.

There are other positive outcomes of this migration for Ukraine's national economy. As Nina Karpachova has pointed out, the migrants earn 400,000,000 (four hundred million) US dollars monthly and the most of these moneys get sent back to Ukraine, either via banks or personal networks. (Karpachova 2003: 54) These moneys contribute significantly to the local economies. New houses began to sprout in rural communities 
because of the migrants' remittances, dramatically changing the local cultural, economic and financial scapes within those communities. Prybytkova also sees this process in a positive light and points out that migrants in general achieve a higher social status and better economic positions on their return to Ukraine (Prybytkova 2003).

Personal sending networks - of friends, co-workers and kin at the level of the rural communities, and later of travel agents - have played a crucial role in directing the migration flows and establishing region- and gender-specific migrant communities throughout Europe. For example, according to Viktor Susak, a Ukrainian sociologist who has surveyed Ukrainian migrants in Portugal, Portugal received its first, mainly male migrants from Ivano-Frankivsk Oblast, and that predetermined the formation of the Portuguese receiving networks, which consisted for a long time of mostly Ivano-Frankivsk Oblast migrants. In Spain, the receiving networks first developed out of migrants from Ternopil Oblast, and most were female, and this subsequently determined the migration flows from this oblast into this country. Gendered communities have also developed recently in Greece, where among twenty or so thousand Ukrainians only 15 percent are men (Susak 2003).

First half a year went by, and we decided that I should go there, so it would be easier for him. I planted all the gardens, finished some work around the house, and on June the $2 d$ [pause] what year was that? 1999? 2000? Yes, on June 2, 2000 , I went to join him. So I went to join him [pause, Anna lowers her voice, saddened by memories].

My trip was not like his. He went there in a German bus, just a regularly scheduled bus, that was not a problem. But we all got cheated, by the Albion company. When we approached the Spanish border, they [the border guards, N.S.] turned our bus around. Because Ukrainians were just flooding the country. Those $\$ 700$ we paid for the trip just went for nothing. So there we were, stuck on the highway, the autobahn. I left the bus. There was a gas station. I left the bus together with another woman from Boryslav. I just could not go back, I had to at least pay off the money I had borrowed for the trip. So there I was, in a state of great despair. The other woman needed to get to the other end of Spain, up to the sea somewhere close to Barcelona, where her husband and her brother were working. So there we were, sitting there for two days at that gas station, dvi doby. Then they [the people working at the station, N.S.] started chasing us away. So we hid in the bushes. We would only come out to the phone booth, they had a phone booth 
there, so we would call from time to time to see whether they [Boryslav, the woman's husband, N.S.] had left for us or not.

NS: Did you have any money with you?

Yes, we had money. We had exchanged some before entering Spain, in

France. This all took place in France. We were waiting for the taxi that would come and pick us up. They, the family, had rented a taxi to get us out of there. So we waited like that for two days, until the taxi finally came. I went with them to Barcelona, or near Barcelona. From there I took a train, so altogether I was on the road for 10 days, from Lviv to Madrid. Finally I met up with my husband. That was such a difficult trip. [pause] Now I understand how it happened. They, the company, had organized a tour. [...] They actually did not plan to go to Spain legally. It was supposed to be an illegal crossing - they would illegally come into the country, unload the people, and the people were supposed to get to their destinations on their own. The Spaniards finally figured out that something was going on and they began to turn Ukrainian buses back. [pause] So they duped us. Not only me, but all 48 of us. [...] Most of them, men, were on their way to Portugal. Here, back in Lviv, they cheated us; they told us that they were taking people as far as Lisbon.

Whoever needed to get off in Madrid, they told us, could get off in Madrid, and those who... [pause] Such was their truth.

With the first wave of migrants leaving the towns and villages, "holes" began to appear, one by one, in local social circles in the rural areas in Western Ukraine in the early 1990s. In Anna's social circle, the entrepreneurial types, with good "connections" in the city, and the teachers of foreign languages were among the first to go. Throughout Western Ukraine, men formed construction brigades and traveled to Russia to do construction work, as in the case of Anna's husband. In Anna's town of Sokal, women first went en mass to Israel:

See, in our community, the very first wave went to Israel. And those who went to Israel were already 50 and older. They earned a good reputation abroad, and good money.

Her friends and neighbours "disappeared," one by one, into the West, leaving behind small children, spouses, and elderly parents. Too often those who departed would never return to those left behind, or they would stay in minimal contact with them. Local folklore started to flourish about the experiences of those on the other side of what used to be the iron curtain. A whole new generation of children, as the local saying goes, the "orphans of living parents," syroty pry zhyvykh bat'kakh, started to grow up in rural Western Ukraine. 
Storytelling, gossiping, and sharing news constitute the new lore on how it is to work and live abroad these days. Such folklore offers many "horror" stories or near horror stories, about virtuous local women becoming concubines and prostitutes and about broken relationships, which, repeated over and over again, over the course of time take on a new quality - one becomes accustomed to these ordeal narratives. If one is considering such a trip, one is prepared for the appearing normalcy of the abnormal. And if one is already back in the community, one uses it as a frame of reference, and a backdrop, for one's own ordeal narrative.

These stories have a direct relationship with the person's sending and receiving networks. Incidents of all kinds which happened to "our people abroad" are reiterated as misfortunes that happened to someone almost known, someone within the person's own, however extended, social circle, a second cousin's buddy, the sister of a neighbour across the street, and so on. One the one hand, these stories are tangible; one would expect them to have power over the individuals. Yet, since they are indeed folkloric in their nature, that is, they circulate in a folkloric fashion, their moral lessons are often ignored by prospectivemigrants.

To legitimize her own choices and moves while abroad, Anna (as did the other women I interviewed), provided many examples of how other women in her new social circles dealt with similar decisions. These stories all underscored Anna's virtues as a hardworking woman with solid principles she would never betray, unlike the women in her stories.

She [a neighbour, N.S.] had a very happy marriage, and she got along very well with her husband. But one day, they were told about some sort of aktsii, they were told that they could to buy those aktsiia, for two thousand [dollars, N.S.]. Something in Uzhhorod, something like you put your money there and it grows very quickly, it was not through the bank [Anna is talking about the pyramid schemes that flourished throughout Eastern Europe in the early 1990s]. The fact is that they put two thousand US dollars into it. [...]

She was in shock when they lost all the money. So now they were in great debt. They had borrowed the money with interest as well, and they needed to pay back both the prime and the interest. Their boy had finished grade nine, and she sent him to study in some sort of college. You [as a parent, N.S.] have to pay for education [of your children, N.S.]. There was also nothing to pay the bills. Their regular salaries were enough for the week only, and not for the month and for repaying the debts. So she went to Italy. 
It's already been three years since she left. The first year she was paying off the debt. She sent her husband money, everything was fine and according to plan. Her husband stayed behind, with two children. Then one day, her husband came to me, I was already back [from Spain, N.S.], so he came, "Nadiu, could you please call her or write her? The situation is such, people have been telling me such things about her... She doesn't call, and when she does, she only talks to the children. She does not want to talk to me, something is going on. I don't recognize her at all. What can I do? What can I do?" Well, it turns out someone had told him that she's living with an Italian! And that's that. She took her oldest son there; the younger son will probably join her. I am now out of touch with her, I am now working in Lviv, and we do not stay in touch any more.

And then another case. A neighbour's family lived next to us. They went together, leaving the children behind with their parents. These children are orphans with living parents abroad. They are in Portugal. They divorced in Portugal and live far away from each other. She's living with someone from Donets'ka oblast, and he's living with someone from somewhere else [...]. Their children are 2 and 5. Children tell stories about their parents. "Tato is coming with titka Natalka, and mama lives there with another vujko, or uncle."

And there is another fellow who went abroad, left his parents and two children. His wife passed away, so he forgot about them. Never writes, neither to his parents nor to his children. But people from there say that he's living with a Portuguese woman.

While in Spain, Anna discovered a morality that was very new to her:

Like anywhere, "our people" don't exactly behave themselves in the best way, there is a struggle for survival going on, there is also capitalism. People right away see what is it all about; there, there is no way people would consider each other a brother, no one helps anyone, no one will help you there if you are in trouble, there is nothing of this kind there. One has to pay for everything there, for work one has to pay, for each favour one has to pay, otherwise no one gives you any information.

In Madrid there are two squares, where our Ukrainians meet, [pause] Aluche and Atoche. They meet in Aluche only on Sundays because that's when all the buses come, busy, that bring parcels in and take money back, that bring Ukrainians, Poles, and so on. Atoche is actually a railway station. There is a nice park there, the Winter Garden, under a roof. It is there that our people get together, there that the jobs are sold.

NS: They sell jobs? 
Only sell! [Anna underlines this.] Nobody gives anything for free. A job costs from $\$ 350$ to $\$ 400$ to $\$ 500$.

NS: How does it work?

Our people... Our people, the ones who went there earlier, they have already gone through all these ordeals, mytarstva. First it was Poles, Polish women, who were selling jobs. Now they have learned all this, it takes no time to learn this, and now they sell jobs themselves. I went there for a month, to look for a job there. I was in such despair, I can't begin to tell you. Instead of covering our living costs and sending money back home, there I was! My husband needed to provide for me.

I saw and learned so much while going to that square [the job market, N.S.], vsioho nadyvylasia tam. I saw how our women sell themselves. There, those Spaniards, the men come to them, holding in the pocket their 5 milles, it is 5 thousand of their money, some 25 dollars. It was already clear what was going on. And our women, young women and girls, are sitting and waiting for that. Whether that is payment for an hour or something else, I don't know.

Anna had to justify not only the departure, but the return as well. In her narrative, she does it through repeated assertions of her pride and a resultant inability to work as a maid for someone else because of her sense of self-respect.

Finally, I found a job. A woman sells me a job, a woman from Ivano Frankivs'k oblast. So she sells me this job in a family, where there are three children, a husband and wife; they own a chain of stores of some kind. The husband brought his wife from Argentina. The wife was a very nice person. She could not say anything to me [because of the language barrier, N.S.], but they paid me $\$ 10$ a day [Anna laughs]. I was very glad to have at least that job, so I could at least buy groceries so my husband and I could eat together and send money back home.

I felt miserable there. I felt that I was not of that dough to live or be abroad. I just could not... I could not work for others [she means serving others, N.S.]. It seems I am made that way. I cannot work for others. I just cannot go through such humiliation. It hurts so much that I just cannot do it! I just cannot survive it. It is so humiliating. I don't know why, I see our people are working in a very different way and that is ok with them. But I cannot be that way. I cannot [live, stay] in someone's house.

I was so fed up with that humiliation. I don't have too much pride to be above everybody, but I have enough human dignity to feel humiliated as I did while I was working in Spain. I just could not work for someone else. 
The culmination of her narrative is the part of the story in which she redeems herself in the eyes of the woman she was working for as a firstand not second-class citizen. The following episode has been retold many times before I entered Anna's life. The story has already acquired its own structure, sequentiality and pathos.

One day my daughter sent me some pictures from the states, of her at the University of Minnesota where she was studying at the time. There was a small album with those pictures, which I had with me in my purse. I would look through them every once in a while. So she came home [the woman Anna worked for, N.S.], and I was playing with the child with the album lying about. She sort of hinted that it was time for me to go, so I got up and stood next to her. Then she asked me whether it was my daughter in those pictures. By that time we could communicate better. And [by looking at those pictures] she understood... I told her that she, my daughter, was in the states, studying. Oh yea, and Olia had also sent pictures from our home back in Ukraine, pictures with us all sitting around the table, pictures with us celebrating Christmas Eve, Sviat Vechir, something of that kind. And that album had all kinds of pictures and so I showed her all these pictures. And then she asked, "why are you here?" [Anna raises her voice, to imitate the woman's surprise]. You have such a beautiful home, why are you here? And I tried to explain her the best way I could, that we have everything back home except that we have now a very difficult economic situation at this moment, and our people just have to leave the country to make some money. We have everything, but not money. And so because of that stupid damned money, we leave, we sell ourselves, so our children can study. There was no other goal in our case. It was not for a house, it was not for a car for me and my husband, but for our children's education that we decided to go abroad. There was nothing more that I wanted. I wanted to give my children an education, a proper education. Not the kind of education that you can only show on paper, but a real education, a good versatile education they can rely on later in life.

[...] And after that she started calling me Señora. [pause] Only after that.

Like many other informants, Anna never failed to reiterate this particular incident in her story about her ordeals abroad. Retelling it over and over again (I listened to it twice, and two students of mine have heard this story on different occasions as well) allowed her to punctuate her narrative with a period, and not only a literal period. Sharing all her previous experiences abroad in a conversation was done to prepare her listener for this, the culminating point of her narrative. To Anna, this final story is about redeeming herself not only in the eyes of a Spanish employer (to whom she finally became Señora), but in the eyes of her own circles 
back home (listeners included) to whom she never wanted to fail as a Pani (the Ukrainian equivalent of Señora). Most importantly, the final story of becoming Señora is about redeeming oneself in one's own eyes. With this powerful story, Anna ended her narrative and we both fell silent contemplating it, each in our own way.

\section{IN CONCLUSION}

I suggested earlier, drawing on a tradition of work in ethnography and social psychology, that narrating helps a person make her life journey meaningful, as it unfolds both through time and space, and I argued that these meanings subsequently get re-evaluated (in conversations) in relation to and against the networks of relationships in which one is embedded. The thicker and more entangled these relationships are, the better navigational techniques one needs to narrate one's way through these relationships and to recreate one's life-path against their background.

In case of labour migrants from Western Ukraine, one passes on one's way and has to deal with many bundles of social relationships, first leaving family, friends, and networks of neighbours, then often becoming not so much the subject but the object of human labour trafficking controlled by networks of trafficking agents, and eventually adjusting oneself to the social world of former compatriots and to a lesser degree to the host society in the new country.

How does narrative help researchers approach these networks of relationships and networks of meanings? Narrative analysis of life histories allows us to access these networks and understand their dynamics through the examination of at least two narrative techniques: (a) the narrator's effort to associate or dissociate herself with certain social groups; and (b) the narrator's ability to introduce into narrative not just her own viewpoint, but the viewpoints of many other characters present in her story.

(a) The narrator often associates herself with various social groups, whether consciously or subconsciously. In her story, Anna clearly distinguishes between a generic social entity of "our people abroad" and between her own social world back home, to which she often refers with the help of the linguistic phrase $u$ nas, which is hard to translate into English but which is similar to the German expression "bei uns," meaning 
"where I am from," or in our home, in our community, etc. In Anna's case, she does not present herself as integrated into Madrid's Ukrainian community (though she spent a year and a half there); rather she clearly identifies herself with the abstract social entity of "us/our people abroad" that is the six to seven million Ukrainian migrants, forced like her by economic circumstances out of their own country to earn cash. Throughout the storytelling event, Anna talks of herself as a member of her family group, of her Sokal hometown community, of the narrow circle of acquaintances she found in Spain, and of the Ukrainian nation at large. All these choices - to (not) present oneself as a part of a particular social entity - are made contextually and constitute the narrative navigational techniques one relies on to achieve a meaningful rendering of one's life.

(b) The multiplicity of viewpoints often found in migrant narratives sheds much light on the fact that networks are founded on power imbalances not only between individuals but between networks of individuals as well. Of course, one has to be aware that those viewpoints are only narrative presentations of real life people's understandings of their situation, but let us not be distracted by that here. The narrator has empathy with certain persons on whose behalf she is speaking, as she understands them (Schrager 1998: 287). As Schrager reminds us, since the identification changes, so too does the point of view. Thus, as the audience, we are given access to various experiences by means of the differing viewpoints presented by the narrator throughout her story. For example, describing a neighbour's despair over the estranged wife in Italy, Anna assumes his voice citing him directly, thus, indicating her sympathy for his strong moral character and providing another voice in support of her search for dignity abroad. At the same time, she rejects his wife by never giving room to her-the-agent in her story and repeatedly stating that she is not in touch with her anymore. In disassociating herself with the woman, Anna positions herself above the seeming immorality of woman's behaviour towards her husband and children.

In this navigating between various viewpoints, we can also see how positions of power are negotiated between individuals, individuals and the networks they are embedded in, and between social networks themselves. We are once again reminded that a person's involvement in any social network is never neutral. Power positions differ for all individuals, and it is on the basis of this differentiation of power positions that different viewpoints of events and relationships are born. 
This process is accompanied by the formation of complex networks within which these relationships take on meaning, which can be accessed through oral history accounts like Anna's.

Anna's story also helps us to better see how, in the context of labour migration, relationships between various networks, which are constantly under construction, are coming into being. Her narrative relates to us a highly interactive development of entangled and embedded networks, or networks which are feeding off each other. Thus, on the one hand, throughout her journey she is objectified and subjected to manipulation in and by the network of many intermediaries, from traffickers to job sellers, and racketeers. On the other hand, in response to these experiences she develops and maintains her own networks, which she then relies on in order to navigate through the obstacles imposed by the former. The picture is very dynamic and constantly changing. The active participation, and embedded-ness, of a person in such complex interactions of various networks, of people and of their relationships, is what in the end informs a person's vision of her own choices and moves in life as meaningful.

\section{E N D N OTES}

[1] This essay is the product of a prolonged, informative, and very moving interaction that I had with Pani Anna in the summers of 2003 and 2004 (Anna's real name was not used in this essay to protect her identity). I do not feel that I have the right to convert our mutually created story into a typical uni-vocal narrative, in which the voice of the informant is subjugated to the voice of the presumably informed researcher. Anna is as much of an author of this essay as I am, which is why I have not put her story in citation format. Hence, the essay is told in two voices, the first belonging to Anna and the second being mine. I have resorted to distinguishing our voices visually. Therefore, Anna's story is presented in a different colour.

[2] All parts of Anna's story come from the same conversation recorded on July 30, 2003, in Lviv, Ukraine.

[3] This project focuses not so much on the actual experiences of labour migration triggered by socio-cultural changes, but rather on how individuals, in order to justify their own displacement, weave their own personal (her)stories and, thus, create meaning of their life. In doing so, Ukrainian immigrant women come up with a specific form of displacement narrative, relying not only on specific "Ukrainian" cultural means and methods of communicating their experiences to others but on means of communication informed by Soviet and post-Soviet social practices and norms. 
Antoniuk, Anna. Personal communication, July 30, 2003.

Frejka, T., Okolski M., and Sward K. (eds). "In-Depth Studies on Migration in Central and Eastern Europe: The Case of Ukraine." In Economic Studies. No 12 (A publication by the United Nations Economic commission for Europe, United Nations Population Fund). United Nations: New York and Geneva. 1999.

Hannerz, Ulf. Cultural Complexity: Studies in the Social Organization of Meaning. New York: Columbia University Press. 1992.

Maksymiuk, Jan. "Millions of Ukrainians Work Illigeally Abroad." RFE/FL Poland, Belarus, and Ukraine Report. April 3, 2003.

Moore, Sally. 1987. "Explaining the Present: Theoretical Dilemmas in Processual Ethnography." American Ethnologist 14 (4) 1987. 727-736.

Karpachova, Nina. "Svitova problema mihratsii vysokokvalifikovanoi robochoi syly ta vidtik intelektu z Ukrainy (Worldwide problem of braindrain migration from Ukraine)." In Ekonomichna mihratsiia z Ukrainy: prychyny ta naslidky (Economic Migration from Ukraine: Couses and Consequences) (ed. by I.Vynnychenko). Kyiv: Institute for Diaspora Research, 2003: 42-59.

Prybytkova, Iryna. "Labour Migrants in the social hierarchy of a Ukrainian society: status positions, values, life strategies, and the lifestyle, (part 1)" In Sociology: Theory, Methods, Marketing, 2002 (4) : 156-167.

—. "Labour Migrants in the social hierarchy of a Ukrainian society: status positions, values, life strategies, and the lifestyle, (part 2)" In Sociology: Theory, Methods, Marketing, 2003(1) 1109-124.

Schrager, Samuel., "What is social in oral history?" In The Oral History Reader (ed. by R. Perks and A. Thomson). Routledge: London, New York, 1998: 284-299.

Susak, Viktor. Personal communication, July 14, 2003.

Vynnychenko I., "Za 'kruhlym stolom' - pro problemy imihratsii." In Svoboda (Ukrainian newspaper in the USA). October 42002 (40).

Natalia Shostak

St. Thomas More College

University of Saskatchewan, Saskatoon, Canada 